\title{
インパチエンスネクロティックスポットウイルス（INSV）による リンドウえそ斑紋病（新称）
}

\author{
猫塚 修一 ${ }^{1 *} \cdot$ 浜田 博幸 ${ }^{2} \cdot$ 勝部 和則 ${ }^{1,3}$
}

\begin{abstract}
NEKODUKA, S. ${ }^{1 *}$, HAMADA, H. ${ }^{2}$ and KATSUBE, K. ${ }^{1,3}$ (2005). Necrotic mottle disease of gentian caused by Impatiens necrotic spot virus (INSV). Jpn. J. Phytopathol. 71: 183-184.

In April 2004, dwarf gentian (Gentiana sp.) with chlorotic mottle and necrotic spot was found in Iwate Prefecture, Japan. The isolated virus infected six plant species of four families after mechanical inoculation. This is the first report of Impatiens necrotic spot virus (INSV) on gentian and we propose the name necrotic mottle disease of gentian.
\end{abstract}

(Received February 14, 2005; Accepted April 27, 2005)

Key words: gentian, necrotic mottle disease, Impatiens necrotic spot virus.

リンドウ（Gentiana spp.）は，花弁が主に青紫色を呈す るリンドウ科の多年生草本である. 岩手県では切り花用と して露地栽培されているが，近年栄養繁殖性のわい性鉢物 の生産も増加している. 2004年 4 月, 岩手県北上市の八ウ スで鉢物わい性リンドウ品種 “あ括こりん’と“ももこり ん’にえそを伴らウイルスによると思われる病害が発生し た.このリンドウから分離されたウイルスの諸性質を検討 した結果, 本病害がインパチエンスネクロティックスポッ トゥイルス（Impatiens necrotic spot virus, INSV) によること が明らかになったので報告する。

罹病株の病徵 病徵は, はじめ葉に退緑斑紋を生じ, 後 にえそ斑紋を形成した。発病は下位葉から発生し，草丈の 伸長とともに上位葉へと進展した. 症状は茎立ちした数本 の茎葉に現れ, 株全体で発病することは稀であった。 また， 発病茎の伸長は著しく抑制された（Fig. 1A，B）.

病原ウイルスの検索罹病株の病勢進展の特徵から Tospovirus が病原ウイルスであると考兄られたので, 遺伝 子工学的に検索する目的で罹病株と外観健全株の葉から全 RNA をRNeasy Plant Mini Kit（Qiagen 製）を用いて抽出し た. 抽出した全 RNAを鋳型として，トマト黄化えそウイ
ルス（TSWV）とINSV を検出することが可能な degenerate primer（Weekes et al., 1996）を generate に改良した 2 種類 の primer, 即ち TospoUf (5'-TGTAGTGGTCCATTGCA-3') と TospoUR (5'AGAGCAATCGTGTCA-3'), 特よびRNA PCR Kit（Takara 製）を用いてRT-PCRを行い， nucleocapsid protein 遺伝子の一部を含む領域を増幅した。 その結果, 罹病株のサンプルから約870塩基対の目的とする cDNAの 増幅が認められた. 得られたcDNAをpSTBlue-1 Vector (Novagen 製) にクローニング後, 塩基配列を決定したと ころ, 既報の INSV NL-07（de Haan et al., 1992） と塩基配 列で $98.2 \%$, 推定アミノ酸配列で $100 \%$ の相同性が認めら れた（Accession No. AB207803）。 また，罹病株について他 のウイルス感染の有無を明らかにするため, 罹病葉の粗汁 液を抗原とし，リンドウの既知の病原ウイルスであるキュ ウリモザイクウイルス (CMV), ソラマメウイルトウイル ス（BBWV-2），クローバ葉脈黄化ウイルス (ClYVV), お よびTSWVとINSV に対する抗血清（日本植物防疫協会 製）を用いたDAS-ELISA に供試した. その結果，CMV， BBWV-2, CIYVV 抢よびTSWVの抗血清とは反応せず, INSVのみ陽性反応を示した (データ省略).

\footnotetext{
1 岩手県農業研究センター（テ024-0003 岩手県北上市成田20-1） Iwate Agricultural Research Center, Narita, Kitakami, Iwate 0240003, Japan

${ }^{2}$ (財)岩手生物工学研究センター（甬024-0003 岩手県北上市成田22-174-4） Iwate Biotechnology Research Center, Narita, Kitakami, Iwate 024-0003, Japan

3 現在 : (財)岩手生物工学研究センター

* Corresponding author (E-mail: s-nekoduka@pref.iwate.jp)
} 

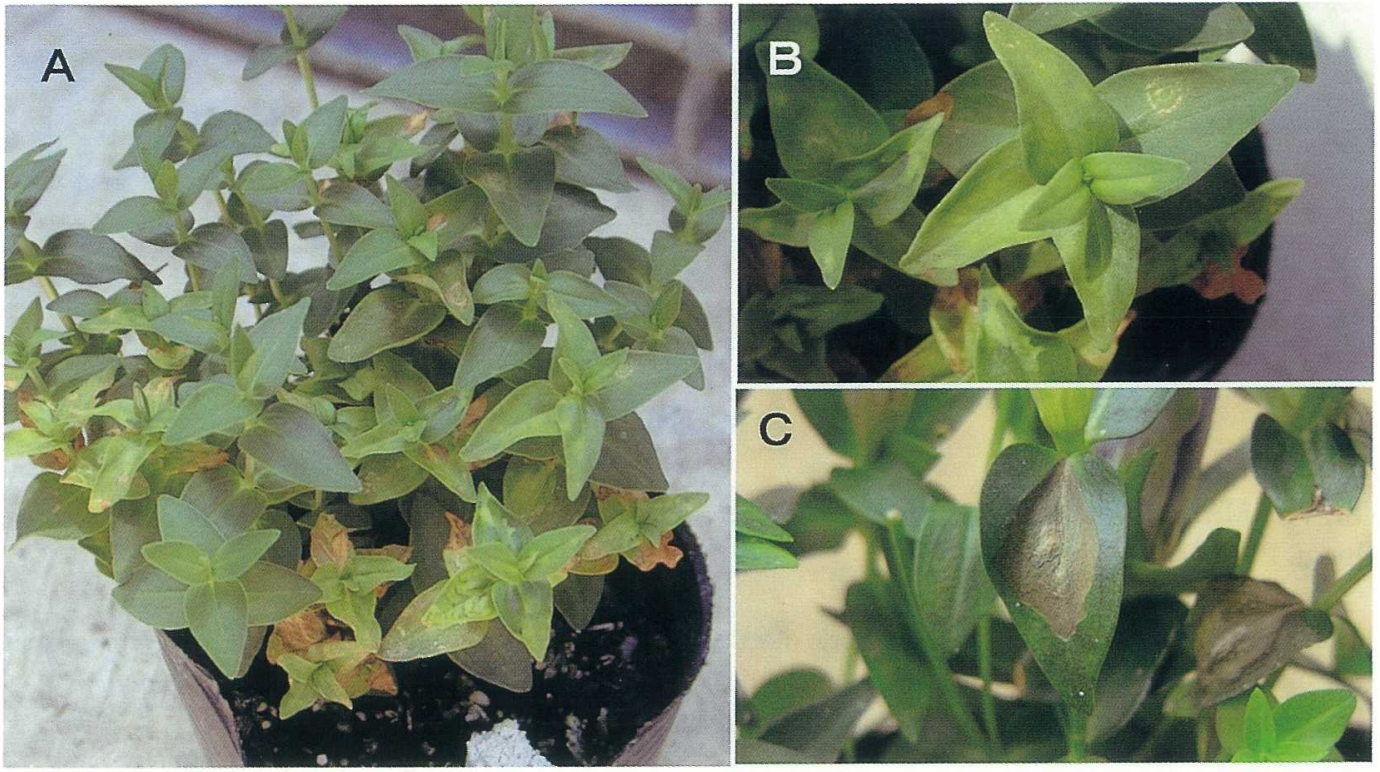

Fig. 1. A, B: Natural symptoms of chlorotic mottle and necrotic spot on gentian. C: Necrotic spots on the leaves of gentian 10 days after inoculation.

ウイルスの単離と接種植物の反応 リンドウ罹病株の兄 そ斑紋症状を呈した葉の粗汁液をぺチュニアに接種し，接 種葉の局部病斑加ら単一病斑分離を 2 回行い, Nicotiana benthamiana で増殖させ分離株 Gii0404を得た。 この分離 株をDAS-ELISA に供試したところ，INSVが検出された。 Gii0404を N. benthamiana で増幅させた後, この感染葉を 5 倍量（W/V）の $0.1 \mathrm{M}$ リン酸緩衝液（pH 7.0, 0.2\%亜硫 酸ナトリウム加用）で磨砕し，カーボランダム法によりリ

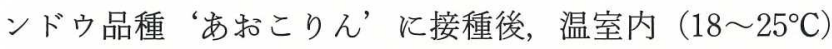
で約 1 ヶ月にわたり病徵を観察した。父の結果，接種 7 日 後に接種葉に兄そ斑紋を生じたが，全身感染は認められ なかった（Fig. 1C)。また，この罹病葉をぺチュニアに接 種し，得られた分離株をDAS-ELISA に供試したところ， INSV が検出された。な扔，Gii0404を接種したりンドウ の全身感染については，翌年以降の茎立ちした茎葉への発 病を含め，引き続き検討する必要がある，本分離株につい てリンドゥを除く 4 科 7 種の検定植物の反応を検討した結 果, $N$. benthamiana とインパチエンスでは全身感染し, $N$. rustica，ペチュニア，センニチユウでは局部感染であった (Table 1)。これら検定植物の反応は，本邦に発生した既報 のINSV の所見（藤・山本，2000；谷名ら，2001）とほぼ 一致した。

病名 以上のことから，リンドウに発生した光斑紋症 状はINSV の感染によることが明らかになった。リンドウ では INSVをはじめ，Tospovirus による病害発生に関する 報告は国内外に見当たらない。したがって，本病をリンド
Table 1. Host range and symptomatology of the virus isolated from gentian

\begin{tabular}{ll}
\hline Plant species & Symptoms $^{\mathrm{a})}$ \\
\hline Gentiana sp. (cv. Aokorin) & $\mathrm{NS} /-^{\mathrm{b})}$ \\
Gomphrena globosa & $\mathrm{CS} /-$ \\
Impatiens sultani & $\mathrm{NS} / \mathrm{NS}$ \\
Nicotiana benthamiana & $\mathrm{NS} / \mathrm{NS}, \mathrm{N}$ \\
N. rustica & $\mathrm{CS}, \mathrm{NS} /-$ \\
Petunia $\times$ hybrida & $\mathrm{NS} /-$ \\
Phaseolus vulgaris & $-/-$ \\
Vigna unguiculata & $-/-$ \\
\hline
\end{tabular}

a) CS, chlorotic spot; NS, necrotic spot; N, necrosis; -, no symptom.

b) Inoculated/upper leaves

ウ它そ斑紋病（Necrotic Mottle Disease of Gentian）と呼称 することを提案する。

\section{引用文献}

de Haan, P., de Avila, C., Kormelink, R., Westerbroek, A., Gielen, J. J. L., Peters, D. and Goldbach, R. (1992). The nucleotide sequence of the S RNA of Impatiens necrotic spot virus, a novel tospovirus. FEBS Letters 306: 27-32.

藤 晋一・山本英樹 (2000). 秋田県に括村るImpatiens necrotic spot virus（INSV）の発生. 北日本病虫研報 51: 122-125.

谷名光治 - 井上幸次 - 伊達寛敬 - 奥田 充 - 花田 薰 - 那須 英夫・粕山新二 (2001). インパチエンスネクロティック スポットウイルスによるシネラリア完等斑紋病。日植病報 67: 42-45.

Weekes, R. J., Mumford, R. A., Barker, I. and Wood, K. R. (1996). Diagnosis of tospoviruses by reverse-transcription polymerase chain reaction. Acta Horticulturae 431: 159-166. 